\title{
The Dilemma of the Process-Oriented and Spillover Effects of Regional Economic Integration of West Africa: ECOWAS Intra-regional Trade and Trade with Key External Trading Partners
}

\author{
Benjamin Akwei, Ph.D* \\ Adjunct Assistant Professor International Relations \& amp; Comparative Politics \&amp; Government (Africa \& amp; \\ Middle East). University of Bridgeport College of Public \& amp; International Affairs 303 University Avenue \\ Bridgeport, CT. O6604. USA
}

*Corresponding Author

Benjamin Akwei, Ph.D

Article History

Received: 02.06.2020

Accepted: 12.06.2020

Published: 17.06 .2020

\begin{abstract}
After over two decades of the revision of the Economic Community of West African States (ECOWAS) treaty, which stipulated a common market, including a common external market, the Head of States of the Community as part of fast-tracking their regional integration process and laying the grounds for the establishment of an effective Customs Union decided to implement the ECOWAS common external tariff (CET) in early January of 2015. The CET, which requires the adoption of the same customs duties application to all goods entering ECOWAS Member States, regardless of which country within the area they are entering also requires careful preparation and communication by member ministries. The adoption of the CET according to trade experts will also prompt reaction from firms and producers, as external competition from imports will change. Despite the myriad of challenges facing the Community and its consciousness of the overriding need to accelerate, foster and encourage the economic and social development of their states in order to improve the living standards of their peoples, the question that needs to be addressed is "What has contributed to the lagging behind of the implementation of the Community's ambitious regional integration policies and targets compared to the European Union process-oriented integration theory given that a common trade policy does not only define the trade relations with the third-parties but also with the member States within the internal market?.
\end{abstract}

Keywords: ECOWAS, Customs Union, Common External Tariff, Regional Integration \&amp; Process-Oriented Integration theory.

\section{INTRODUCTION}

The 1960s and 1970s marked a crucial moment in Africa about the formation of regional groupings. The postwar theorists focus on the political dimension of integration for the peaceful resolution of international conflict, the limitation of the neo-functionalist approach application to less developed countries in East Africa and Central America and post-war economists interest in economic integration in describing the process of economic integration and its impacts on welfare sparked a renewed interest on the effects of integration on trade and other economic activities in the 1960s and 1970's. In West Africa, the Economic Community of West Africa States (ECOWAS), an economic integration trading bloc was formed in May of 1975 to promote integration through economic, social and cultural cooperation but the challenges that the regional grouping faces as a result of colonial legacies: the problematic state, the agrarian economy, ethnic factor and the external dimension calls for a selfless commitment on the part of the governments in the region for a political unity to deal with the last vestiges of colonization. This paper will discuss the theory of regional economic integration as it applies to ECOWAS, with a focus on ECOWAS intra-regional trade and trade between ECOWAS and key highly industrialized trading partners such as China, USA, and the European Union (EU) which buy from the region raw materials and sell back industrialized products (cars, ships, trucks, motorcycles, medicaments, etc.). Emphasis will also be placed on the colonial state and dependency on primary products by suggesting why ECOWAS countries cannot

Copyright @ 2020: This is an open-access article distributed under the terms of the Creative Commons Attribution license which permits unrestricted use, distribution, and reproduction in any medium for non commercial use (NonCommercial, or CC-BY-NC) provided the original author and source are credited. 
continue to see the European process-oriented model of economic integration as a model to economic development with its spillover effect.

\section{Theorizing on Regional Integration}

There are a myriad of theories on defining the concept of regional integration. These definitions mirrored economic interactions between states, and included many actors and factors, in particular transnational and domestic actors. The earliest discussions of integration were whether to refer it as a process or an end product. Integration can be both a process and an end product. It could be defined as a process that leads to a certain state of affairs (Laursen 2007). Integration is the attainment, within a territory, a sense of community and of institutions and practices strong enough and widespread enough to assure, for a long time, dependable expectations of peaceful change among its population [1]. On the other hand regional integration without reference to an end point is (i) the process whereby nations forgo the desire and ability to conduct foreign policy and key domestic policies independently of each other, seeking instead to make joint decisions or to delegate the decision making process to new central organs: (ii) the process whereby political actors in several distinct settings are persuaded to shift expectations and political activities to a new center" [2].There are other definitions of regional integration based on European institutional framework which includes and excludes some states and/or markets which are beyond the scope of this paper. However, the neo-functionalist approach coined by Ernest Haas for the integration of Europe which this paper proposes for the institutional framework for ECOWAS will be examined, but, not as a process but rather as an end point. Neo-functionalism, the traditional regional integration theory by the German Ernest B. Haas in the 1950's for the integration of Europe tried to offer an alternative to the Realist school of thought. Neo-functionalism saw the European integration process as a direct response to functional needs of states. It also foresaw that domestic, transnational, and supranational actors would engage in regional integration to improve their efficiency in governance, given their relative proximity and the various possibilities for collaboration [3]. The European Union, which is the concept of political integration, can be intellectually indebted to process functionalists' theorists such as David Mitrany. Functionalism as an integrative process is linked to the conceptualization of global politics based on growing levels of interdependence among actors whose interests and activities are not coincidental with state frontiers [4]. In the 1940s, a period in which Europe was confronting a profound crisis, functionalism was proposed by David Mitrany as a new international order, based on transnational cooperation. Mitrany's main preoccupation was connected to the efficient administration of limited resources as an essential premise for durable cooperation. The growing complexity of governmental systems has greatly increased the essentially technical, nonpolitical tasks facing nations. The functional approach emphasizes the common index of need, there are many needs which cut across national boundaries, and an effective beginning could be made by providing joint government for them [6]. On such lines, the emergence of so many new national states in the post-war era, politically adds to our difficulties, and these difficulties might even be put into the service of international unification. That, if these newly formed national states are to achieve a promising social foundation for their political independence they need many things in the way of material and technical help and service which are beyond their means and experiences as in the case of the Marshall Plan. Such tasks did not only created a demand for highly trained specialists at the national, but also contributed to essentially technical problems at the international levels, whose solution lies in the collaboration among technicians, rather than political elites [4]. Contemporary theorizing on integration since the 1970 s tends to focus upon the structural and institutional dimensions. The institutional dimensions or best known as neo-functionalism has come to dominate International Relations integrative process. Notable neo-functionalist includes Ernst Haas, Joseph Nye, Robert Keohane, and Philippe Schmitter. These neo-functionalists focus their attention on the formation and evolution of the European Community. Neofunctionalism theory of integration centers on refining functionalist theory with a critique of Mitrany for having taken insufficient accounts of the political elements in integration. The neo-functionalist theory of integration was developed to explain European Integration with the European Coal and Steel Community (ECSC), (1952). This conceptual framework illuminates the process of regional integration in the European environment and in less developed areas of the world as well. Haas studied integration efforts in both industrial and non-industrial settings. Ernst Haas and Philippe Schmitter [14], Mexico and Latin America Economic Integration, in their examination of European integration focused on the (ECSC) and what is known today as the European Union (EU) but raised the question of whether economic integration of a group of nations automatically triggers political unity". The theory of economic integration raised by Haas and Schmitter is critical in examining ECOWAS, by analyzing whether it will trigger an automatic unity. Haas and Schmitter in their analyses of the question they posed contend that in modern economic conditions the relationship between economic and political action had best be treated as a continuum. Haas maintains that economic integration will have more spillover into a broad range of political issues than will any other neo-functional approach. The core concept of Haas neo-functionalism is the functional spillover effect that cooperation in one policy area, placing it on the political agenda will lead to further integration. Neo-functionalism spillover effect, Haas theory, then, was based on the assumption that cooperation in one policy area, placing it on the political agenda, and ultimately leading to further integration. Thus, spillover refers to a situation where cooperation in one field necessitates cooperation in other areas [20]. Neo-functionalism theoretical framework to European integration spillover refers to the way in which the creation and deepening in one creation sector creates pressures for further economic integration within and beyond that sector and greater authoritative capacity at the European level. Spillover is the major driver of integration and that it exists in three 
varieties-functional, political and cultivated. Political and cultivated spillovers which are the subject of this paper according to Haas and Schmitter are the result of deliberate pressure exerted by national elites because they expect to benefit from integrative steps and points to the role of supranational institutions respectively. Neo-functionalism as an integration theory elaborates that member states will work together to reap economic benefits, setting in motion a process in which ever more tasks are delegated to the supranational level [18]. European integration is rooted in the pluralist school of regional integration which considers politics to be a group-based activity and believes that all interests will eventually organize to affect decision. Neo-functionalism is a self-perpetuating process once the first integrative steps are taken. The spillover drives defines neo-functionalism integration in the context of Europe as "The political process whereby political actors in several distinct national settings are persuaded to shift their loyalties, expectations and political activities towards a new nation state [26]. The end result of a process of political integration is a new political community superimposed on the pre-existing ones [18]. Critics of the neo-functional theory of integration argue that it lacked a theoretical solid base for its observation as well as the kind of incremental political integration that it predicted that did not take place. Following the crisis of European integration in the mid-1960s, Haas [14] himself bemoaned his gullibility in not anticipating the rejuvenation of nationalism and "anti-functionalism of high-politics" [14, 30]. This notwithstanding, regional integration may conceptualized as a process where, on the one hand, certain group of actors with specific interests consistently engage in lobbying governments for certain outcomes [5]. Form the 1970s onwards political cooperation seemed less compelling, and researchers became more interested in other theories, especially those that stressed the importance of the nation state. Haas, recognizing the limitation of neo-functionalism was compelled to state in 1975 that "the prognoses often do not match the diagnostic sophistication, and patients die when they should recover, while others recover even though all the vital signs look bad" [20]. The economic theorist whose work sparked interests in examining the effects of integration on trade and other economic activities in the post-Second War period as applicable to ECOWAS was Bela Balassa.

\section{The European Process-Oriented Model of Economic Integration}

Bela Balassa [9] "The Theory of Economic Integration" identified stages, political and ideological aspects of the integration process, and specified what economic welfare meant. The author identified Economic integration as a process and as a state of affairs. As a process, it encompasses measures designed to abolish discrimination between economic units belonging to different national units, views as a state of affairs, it can be represented by the absence of various forms of discrimination between national economies. The post-Second World War II period has seen an enormous increase in the interest in problems of economic integration. In Europe the Customs Union and later the economic union of the Benelux countries, the ECSC, the European Economic Community (Common Market, and the European Free Trade Association are manifestations of this movement. Economic integration can take several forms that represent varying degrees of integration. These forms of economic integration as customs union, a common market, an economic union, and a complete economic integration. Balassa contends further that in examining economic integration in the case of Europe, political objectives are great consequences. The avoidance of future wars between France and Germany, the creation of a third force in world politics, and the reestablishment of Western Europe as a world power are frequently mentioned as political goals that would be served by economic integration. Many regard these as primary objectives and relegate economic integrations to second place [9]. The history of the European Union since its inception as an economic community to its current form as a monetary union reveals the process of achieving the spillover effect towards a political unity. As much as neo-functionalism theoretical approach to European integration overrated predictions about integration especially the kind of incremental political integration and role of supranational organization, its challenges against the sovereignty of the nation state was relevant in May 1975 in the regional integration of West African states.

\section{Customs Union as a Trade Policy for the Process of Development and Economic Integration of West African States}

The West African sub- region as part of accelerating; fostering; and encouraging economic and social development of their Member States through Customs Union (this involves besides the suppression of discrimination in the field of commodity movements within the union, the equalization of tariffs in trade with nonmember countries) found out that trade liberalization and specialization and its attendant benefits would benefit this goal of economic development. Milton A. Iyoha in his literature Economic Development and Trade Theories: Relevance and Implications for ECOWAS [22] posed the question how far is this belief buttressed by trade theory? In an attempt to explore this question Iyoha argues that free trade, which is the ideal in the orthodox theory, leads to the efficient allocation of economic resources in all trading countries and hence to the highest amount of world output. ECOWAS, which was founded in the context of Customs Union under the trade theory from an analytical perspective, provides a meaningful vehicle for the increase in trade, linkage, and economic development [23]. Customs Union among Less developed countries will not automatically lead to economic development in member countries but rather it facilitates economic development. Thus, though by no means a sufficient condition for economic development, it may well be a necessary condition for such development in many of the ECOWAS countries. This is because of its beneficent role in industrialization-which is increasingly becoming a handmaiden, if not a prerequisite, of economic development [19]. Customs Union theory proposed by Jacob Viner in his seminal work Customs Union Issue [26] identified the gains from 
trade creation, trade diversion and terms of trade. Trade creation which happens to be the mantra behind ECOWAS Member States' desire to embark upon economic development with its prerequisite of industrialization to a unioninduced shift from the consumption of higher-cost domestic products in favor of lower cost product of the partner country is without comparison to that of developed nations. In a more profound comparison of trade creation in less developed and developed countries, the fact of the matter is that the conditions which are favorable to trade creation are the opposite of those typically found in developing countries, whose existing external trade is usually large relative to their domestic production and whose intra-trade is a minor component of their total trade [19]. Trade creation effects of customs unions are likely to be realized in either of two ways: the conventional theory of comparative advantage and the new trade theory of increasing returns in differentiated markets, both resulting from decrease in transaction costs that should occur with freer trade [23]. The new trade theory emphasizes that increasing returns in differentiated markets will lead to members of the sub-region liberalizing trade through specializations within the customs union based upon variations in market preferences rather than on variations in factor costs. The increasing returns in differentiated markets arguably through trade liberalization and specialization will generate a wider market and surplus revenues for industrialization and facilitate economic development. Whilst the full implementation of a Free Trade Agreement (FTA) in the ECOWAS is still ongoing, the ECOWAS Heads of States have decided to fast-track the regional integration process through the recent implementation of the ECOWAS CET from January 1, 2015. This is indeed a significant development towards laying the ground for the establishment of an effective Customs Union. However, ECOWAS has not yet completed the design for its common trade policy which is the second precondition for customs union enforcement. In general, a common trade policy does not only define the trade relations with the third-parties but also with the member States within the internal market [29].

\section{The Legacies of the Colonial State and the Dilemma of the Dependence on Trade for Development in West Africa}

The proponents of ECOWAS in the mid-1970 adopted the European process integration theory without taking into consideration the historicity of the countries of the region. The over four decades since the formation of ECOWAS, the vestiges of colonial legacies have limited a rapid development of the region to take advantage of the spillover effect of political integration and rather the region has been bisected with a barrage of challenges. In examining why the European process-oriented integration model is a misnomer to regional integration in West Africa, the legacies of colonialism must be explored to serve as a departure for addressing the development challenges and conflicts that confronts the region in the $21^{\text {st }}$ century. The African colonial state has been cited in many books and literatures as a contributing factor to the continent (in this case ECOWAS) slow development. Crawford Young [12], The African Colonial State in Comparative Perspective, suggests that the exceptional features of the colonial state, arising from exigencies of its own reproduction, produced a singularly difficult legacy for the postcolonial state. Young argues that one consequential factor in the crisis faced by most African states (in this case ECOWAS states) by the late 1970's- and intensifying since- was the singularly difficulty bequeathed by the institutions of rule devised to establish and maintain alien hegemony. Young argues that after independence was won the new leaders of the new states were confronted with a crisis of legitimation, revenue imperative that drove the colonial state along diverse pathways, and accumulation: which meant fostering metropolitan dominated trade and a labor force not locally available through market mechanisms, and where coercive conscription would challenge legitimation and security. On the colonial legacy of the African state , Goran Hyden [17], African Politics in Comparative Perspective, argues that the state in Africa is problematic for three specific reasons: it lacks the autonomy from society that makes it an instrument of collective action; the state officials do not adhere to the formal rules that constitute public authority; and that individuals appointed to public office rarely subordinate their personalities to the definitions of the role they are expected to perform. As a result of the lack of autonomy, African societies are stronger than the states thereby calling into question government authority in some countries such as Liberia, Sierra Leone, Ivory Coast, Niger and Mali. These factors that Hyden describes as characterizing the African state raises grave concerns for any effective path to development. The most challenging colonial legacy that has impeded the rapid development of the sub-region in Haas' process-oriented integration theory with its spillover benefits is what Goran Hyden characterizes as the "agrarian question". Hyden argues that transforming agriculture in Africa was one of the principal objectives of the colonial powers; as a result the colonial powers spent a lot of energy trying to bring the largely subsistence-oriented farmers into the market economy and thereby stimulate their interest in producing more. The author emphasizes further that the colonial powers realized the problems of fulfilling demands in the mother country through support of peasant farmers only and therefore embarked on establishing largescale plantations for growing crops that were in especially high demand at the time in Europe. The purpose of agriculture during the colonial period was to extract wealth from the African soil resulting in the intensification of land use in certain parts of Africa. The legacy of this colonial agricultural project was that at the end of the colonial period, African states and farmers had developed an uneasy relation of dependence of primary goods for exports as a major source of national income. The primary products in the years to come have become elastic and subject to price fluctuations on the world market, hence putting development goals into jeopardy. The below table reveals the dilemma of the homogeneity of ECOWAS Member States main primary exports to European Union in 2010. 
Table-1: ECOWAS Countries Main Exports by Country to the European Union in 2010

\begin{tabular}{|l|l|}
\hline Country & Main Exports \\
\hline Benin & Metalliferous ores, metal scarp, textile fibers \\
\hline Burkina Faso & Gold, non-monetary, ores and concentrates \\
\hline Cape Verde & Fish, articles of apparel and clothing accessories \\
\hline Gambia & Fixed vegetables fats and oil, crude, refined and fractionated, fish \\
\hline Ghana & Cocoa, tea, coffee, spices, fish \\
\hline Guinea & Metalliferous ores and metal scrap, petroleum and related products \\
\hline Guinea Bissau & Crude rubber, coffee, tea, cocoa, spices \\
\hline Cote D'Ivoire & Coffee, tea, cocoa, spices petroleum and petroleum related products \\
\hline Liberia & Other transport equipment, petroleum and petroleum related pdts \\
\hline Mali & Textiles, fibers, vegetables and fruits \\
\hline Niger & Inorganic chemical, vegetables and fruits \\
\hline Nigeria & Petroleum and related products, gas, natural and manufactured \\
\hline Senegal & fish, vegetables and fruits \\
\hline Sierra Leone & Non-metallic mineral manuf., metalliferous ores\& manufactures \\
\hline Togo & Coffee, tea, cocoa, metalliferous ores and metal scrap \\
\hline
\end{tabular}

Source: Nicolas Mavraganis, (Eurostat, online Data Code: DS 018995)

The table above shows the main products exported to EU-27 in 2010 by individual ECOWAS Member States were metal ores (Benin, Guinea), gold (Burkina Faso), Fish (Cape Verde, Senegal), Vegetables fats (Gambia), Cocoa (Ghana, Cote D'Ivoire, Togo), crude rubber (Guinea-Bissau), other transport equipment (Liberia), textile fibers (Mali), organic chemicals- Uranium oxide- (Niger), petroleum (Nigeria) and non-metallic mineral manufactures (diamonds) (Sierra Leone). The diversity of the of ECOWAS Member States with widely differing natural resources, primarily primary products and differing degrees of ability makes them to be exploited, putting them in the Wallenstein's "Core" characterization in the world economic systems. The share homogeneity of some of the products in the individual countries does not encourage large scale intra-regional trade. Since most of the products exported are primary products, it means all of them earn the bulk of their foreign exchange from primary products, whose demand are price elastic and subject to price fluctuations. However for those individual countries, those engaged in manufacturing, existing industries will not help them deal with processing of primary products. Unfortunately, thus far, ECOWAS countries (as well as LCDs) concentrate in the lower stages of processing both for technological reasons and because advanced countries use tariffs to discourage the export of processed primary goods from LCDs [19]. The regional trade policy is developed along the lines of boosting exports to member states as well as to the rest of the world. Imports into the region are therefore seen as complementary to the exports of goods and services [22]. Trade in goods is classified into three broad categories: natural resources, food and agriculture, and manufacturing. Table 2 below shows key products of intra-ECOWAS trade in 2015

Table-2: Key Products of Intra-ECOWAS trade, million US\$ and per cent share in total (2015)

\begin{tabular}{|l|l|l|}
\hline Products & US\$ million & Share (per cent) \\
\hline Petroleum oils, oils from bitumen materials, crude & 3140 & 31.3 \\
\hline Petroleum oils or bitumen mineral > 70 \% oil & 1707 & 17.0 \\
\hline Lime, cement, fabrica, constr. Mat. (excluding glass, clay) & 342 & 3.4 \\
\hline Tobacco, manufactured & 250 & 2.5 \\
\hline Edible products and preparations, n.e.s & 242 & 2.4 \\
\hline Perfumery, cosmetics or toilet paper. (excluding soap) & 234 & 2.3 \\
\hline Fixed vegetable fats and oils, crude, refined, fract. & 225 & 2.2 \\
\hline Articles, n.e.s, of plastics & 216 & 2.2 \\
\hline Electric current & 182 & 1.8 \\
\hline Footwear & 148 & 1.5 \\
\hline
\end{tabular}

Source: UNCTADstat.

Note: Merchandise trade matrix export figures are used

Table 2 above, shows that in 2015 the top three key products of intra-ECOWAS trade were in petroleum oils, oils from bitumen materials, crude, lime, cement, fabrica and construction material (excluding glass, clay). These three top key products in 2015 amounted to US\$5,189 million and a total percentage of $51.7 \%$ of total intra-trade. As in the case of total ECOWAS trade, intragroup trade includes limited range of products such as fuels, tobacco, sea and river navigation equipment and cement. Petroleum products alone account for 48.4 per cent of intra-ECOWAS trade in 2015. In addition, there are other products, including live cattle, cereals, tubers, roots and their derivatives, vegetable oils, etc. 
which are mainly traded informally, and are therefore poorly documented. The below table shows ECOWAS members intra-regional trade in percent in 2015.

Table-3: Share of ECOWAS members in Intra-regional Trade (2015, per cent)

\begin{tabular}{|l|l|l|}
\hline Country & Exports $(\%)$ & Imports (\%) \\
\hline Benin & 4.8 & 3.3 \\
\hline Burkina Faso & 1.4 & 11.3 \\
\hline Cabo Verde & 0.01 & 0.1 \\
\hline Cote D'Ivoire & 257 & 18.4 \\
\hline Gambia & 0.2 & 0.6 \\
\hline Ghana & 4.5 & 25.7 \\
\hline Guinea & 0.6 & 1.2 \\
\hline Guinea Bissau & 0.01 & 0.3 \\
\hline Liberia & 0.03 & 0.4 \\
\hline Mali & 1.6 & 9.5 \\
\hline Niger & 2.8 & 6.7 \\
\hline Nigeria & 44.6 & 14.0 \\
\hline Senegal & 8.5 & 5.5 \\
\hline Sierra Leone & 0.02 & 1.8 \\
\hline Togo & 5.2 & 1.2 \\
\hline
\end{tabular}

In 2015, the total value of ECOWAS trade in goods (sum of exports and imports) was estimated at US\$ 190 billion whilst the regional trade represented only US\$19.1 billion, i.e., about 10.0 per cent of total trade. From the table 3 above, out of 15 member States four countries, Nigeria, Côte d'Ivoire, Ghana and Senegal, captured the significant share of the intra-group trade. Combined, these four countries account for 83.3 per cent and 63.6 per cent of intra-group exports and imports respectively (UNCTAD 2018). Most of ECOWAS trade in goods is with external trade partners.

External trade of ECOWAS is dominated by a number of products and generates local value added due to the preponderance of fuels coming from extractive industry. These present three-quarters $(75 \%)$ of exports (excluding reexports) and are provided mainly by Nigeria (73\%). Cocoa and cocoa food preparations (5\% of exports), precious stones (3\%) and secondarily cotton, edible fruits, plastics, wood and wood products, fish and shellfish (about 1\%), form together with fuel, the major export products of the West African Economic Community [23]. The structure of ECOWAS trade in goods with the rest of the world is dominated by exports destined mainly for the European Union, China, India and the United States of America [29].

As for regional imports, they are dominated by about ten products. Fuels still hold a leading position in these lists. They represent $24 \%$ of total imports. They are followed by motor vehicles, tractors, cycles and other vehicles $\left(2^{\text {nd }}\right.$ place), machinery, mechanical appliances and boilers $\left(3^{\text {rd }}\right)$, machinery and electrical appliances $\left(4^{\text {th }}\right)$, cereals $\left(5^{\text {th }}\right)$, plastics $\left(6^{\text {th }}\right)$, works in iron, iron and steel $\left(7^{\text {th }}\right)$, iron, cast iron, steel $\left(8^{\text {th }}\right)$, pharmaceuticals $\left(9^{\text {th }}\right)$ and fish and sea food $\left(10^{\text {th }}\right)$. As for exports, Nigeria appears here also in a dominant position by making alone $41 \%$ of transactions against $18 \%$ in Ghana, $10 \%$ each for Senegal and Cote D'Ivoire. Nigeria and Ghana together perform $59 \%$ of the Community imports against $36 \%$ for the eight Countries of the West African Economic and Monetary Union (WAEMU). The other five Countries of ECOWAS Member States realize only 5\% of the Community imports (ECOWAS 2016). Priority is placed on ECOWAS external trade in goods with EU, US and China. Table 4 below shows European Union (EU) trade flows and balance with ECOWAS from 2009-2019.

Table-4: Total Goods: EU Trade Flows and Balance with ECOWAS, Annual Data 2009-2019

\begin{tabular}{|l|l|l|l|}
\hline Year & Imports (Value Mio $€$ & Exports (Value Mio $€$ & Bal. (Value Mio $\boldsymbol{€}$ \\
\hline 2009 & 15,719 & 17,151 & 1,432 \\
\hline 2010 & 20,238 & 20,094 & -144 \\
\hline 2011 & 30,895 & 25,083 & $-5,812$ \\
\hline 2012 & 37,221 & 24,529 & $-12,692$ \\
\hline 2013 & 34,071 & 27,110 & $-6,961$ \\
\hline 2014 & 33,564 & 28,152 & $-5,412$ \\
\hline 2015 & 26,007 & 26,739 & 732 \\
\hline 2016 & 18,740 & 22,749 & 4,009 \\
\hline 2017 & 22,784 & 25,574 & 2,790 \\
\hline 2018 & 29,669 & 28,365 & $-1,304$ \\
\hline 2019 & 31,315 & 28,908 & $-2,406$ \\
\hline
\end{tabular}

Source: Eurostat Comext Statistical Regime 4 
Table 4 above shows that from 2009-2019, there was a gradual increase in EU total imports from ECOWAS. The highest trade in goods between the EU and ECOWAS was recorded in 2012 in the amount of approximately $€ 61.8$ billion. Of this amount approximately $€ 37$ billion and $€ 24.5$ billion represent EU total imports and exports respectively to ECOWAS. The table also reveals that between 2010 and 2014 there were trade deficits and trade surpluses between 2015 and 2019 respectively. The EU is West Africa's biggest trading partner and the main export market for West African transformed products such as fisheries, agribusiness, textiles etc. The West African sub-regions main exports to the EU consist mainly of fuel and food products. The region's exports from the EU consist mainly of fuels, food products, machinery, and chemicals and pharmaceutical products. In 2016, the EU accounted for $24.5 \%$ of West Africa's exports and $28.5 \%$ of West Africa's imports. In value, EU - West Africa trade amounts to $€ 45.5$ billion. In terms of sectors, West Africa's exports to the EU consist mainly of fuels (51.9\%) and food products (33.8\%). West Africa's imports from the EU consist of fuels $(28.6 \%)$, food products $(12.0 \%)$, machinery $(26.7 \%)$, and chemicals and pharmaceutical products (12.5\%) (EU-West Africa EPA 2017). Table 5 below shows China trade in goods with ECOWAS states from 2009-2018. All these figures are reported by China.

Total Goods: China trade in goods with ECOWAS- (2009-2018)

\begin{tabular}{|l|l|l|l|}
\hline Year & $\begin{array}{l}\text { China Exports to ECOWAS US\$ m } \\
\text { Unadjusted }\end{array}$ & $\begin{array}{l}\text { China Imports from ECOWAS US\$ m } \\
\text { Unadjusted }\end{array}$ & $\begin{array}{l}\text { Trade Balance US\$ m } \\
\text { Unadjusted }\end{array}$ \\
\hline 2009 & 13,936 & 1,395 & 12,544 \\
\hline 2010 & 18,980 & 1,844 & 17,136 \\
\hline 2011 & 24,917 & 2,909 & 22,008 \\
\hline 2012 & 26,784 & 3,899 & 22,885 \\
\hline 2013 & 27,720 & 5,523 & 22,197 \\
\hline 2014 & 32,432 & 7,207 & 22,225 \\
\hline 2015 & 31,794 & 3,802 & 27,992 \\
\hline 2016 & 26,091 & 3,888 & 22,203 \\
\hline 2017 & 29,231 & 5,800 & 23,431 \\
\hline 2018 & 31,266 & 7,754 & 23,512 \\
\hline
\end{tabular}

Source: UNComtrade data from 1998-2018, http://comtrade.un.org.data

Table 5 above shows that ECOWAS member states total exports and imports to China between 2009 and 2018 were $\$ 44,021 \mathrm{~m}$ and $263,151 \mathrm{~m}$ respectively. The highest exports and imports were recorded in 2018 and 2014 , totaling $\$ 7,754 \mathrm{~m}$ and $\$ 32,432 \mathrm{~m}$ respectively. The table also shows that within the 10 years period under consideration ECOWAS member States recorded trade deficits totaling $\$ 216,133 \mathrm{~m}$, with the highest trade deficits being recorded in 2015 . Also the table shows that there were a gradual but insignificant increases in ECOWAS trade exports to China from 2009-2014. The main product China exports to West Africa are machinery and electronics, textile and apparel, hi-tech products and finished goods. ECOWAS imports to China concentrates on crude oil, non-ore, cotton, diamond, and other natural resources and primary goods.

Total Goods: U.S trade in goods with ECOWAS States from 2009-2018.

\begin{tabular}{|l|l|l|l|}
\hline Year & $\begin{array}{l}\text { U.S. Exports to ECOWAS US\$ m } \\
\text { Unadjusted }\end{array}$ & $\begin{array}{l}\text { U.S Imports from ECOWAS US\$ m } \\
\text { Unadjusted }\end{array}$ & $\begin{array}{l}\text { Trade Balance US\$ m } \\
\text { Unadjusted }\end{array}$ \\
\hline 2009 & 5,674 & 1,242 & 4,432 \\
\hline 2010 & 6,565 & 1,748 & 4,817 \\
\hline 2011 & 8,070 & 2,972 & 5,098 \\
\hline 2012 & 8,330 & 3,027 & 5,303 \\
\hline 2013 & 9,938 & 4,301 & 5,637 \\
\hline 2014 & 9,928 & 5,646 & 4,282 \\
\hline 2015 & 6,125 & 3,681 & 2,444 \\
\hline 2016 & 4,198 & 6,103 & $-1,905$ \\
\hline 2017 & 4,829 & 9,604 & $-4,775$ \\
\hline 2018 & 5,782 & 7,980 & $-2,198$ \\
\hline
\end{tabular}

Sources: UNComtrade data from 1998-2018, http://comtrade.un.org.data; U.S Census Bureau,

Trade in Goods with Ghana from 2009-2018, http://census.gov/foreign-trade/balance

Table 6 above shows that from 2008 to 2019, the highest total exports of total goods from the 15 Member ECOWAS States to the US totaling $\$ 9,604 \mathrm{~m}$ was recorded in 2017 , followed by $\$ 7,980 \mathrm{~m}$ in 2018 . Within the same time period, total imports of total goods by ECOWAS Member States from the US totaling $\$ 9,938 \mathrm{~m}$ was recorded in 2018 , followed by $\$ 9,928$. The sub-region's region recorded a gradual trade deficits from 2009 to 2015 , the highest being 
$(\$ 5,637 \mathrm{~m})$ in 2013 . The table also shows that in 2017 when the ECOWAS region recorded its highest total trade in goods, it also recorded its second lowest imports from the US in the amount of $\$ 4,829 \mathrm{~m}$. Statistics from the Office of the U.S trade Representative in 2020 shows that U.S. goods exports to ECOWAS countries in 2017 were $\$ 4.8$ billion, up $15.0 \%$ (\$631 million) from 2016.The top 5 U.S. export markets in the ECOWAS countries for 2017 were: Nigeria ( $\$ 2.2$ billion), Ghana ( $\$ 860$ million), Togo ( $\$ 482$ million), Cote d'Ivoire (\$320 million), and Benin ( $\$ 250$ million).The top export categories (2-digit HS) in 2017 were: vehicles and parts ( $\$ 983$ million), mineral fuels ( $\$ 939$ million), machinery (\$606 million), cereals ( $\$ 527$ million) and plastics ( $\$ 287$ million).U.S. goods imports from ECOWAS countries in 2017 were $\$ 9.3$ billion, up $58.6 \%$ (\$3.4 billion) from 2016.The top 5 U.S. import suppliers from the ECOWAS countries for 2017 were: Nigeria ( $\$ 7.1$ billion), Cote d'Ivoire ( $\$ 1.2$ billion), Ghana ( $\$ 750$ million), Liberia (\$91 million), and Senegal (\$72 million).The top import categories (2-digit HS) in 2017 were: mineral fuels (\$7.5 billion), cocoa and cocoa products ( $\$ 1.2$ billion), rubber ( $\$ 160$ million), edible fruit \& nuts (cashews) ( $\$ 88$ million), and artificial flowers, feather or down articles (\$57 million, (www.ustr.gov). A careful analysis of tables 1-6 reveal that most of the exported products by ECOWAS countries are of low value added composition: they are mainly in their raw state or in few cases semi-processed. The implication of this is that most ECOWAS countries do not process their products, which reduces the value-chain and limits the associated potential to trade among themselves. Thus, efforts and policies such as increased investments in the processing of products in ECOWAS countries will be laudable in enhancing the intra-regional tradability as it will help to reduce the effects of too many similarities in the main line of export products. This will increase trade diversity and intensify the penetration as well as competitiveness of their products [22].

\section{The Challenges of Customs Union as a Trade Policy for the Process of the Economic Integration and Development of West African States}

ECOWAS trade policy was meant to foster the smooth integration of the region into the world economy with due regard for the political choices and development priorities of Member States in the desire to engender sustainable development and reduction of poverty. Trade in the Community is evolutionary. Time there was when old trading links were still being relied on to sustain business exchanges in the area. What is being awakened now however is trade with development dimension? ECOWAS, since its inception has had a trade policy designed to increase intra-regional commerce, raise trade volume and generally galvanize the economic activities within the region in such a way as to positively impact on the economic wellbeing of ECOWAS citizens [5]. However, the share homogeneity of some of the products in the individual countries has contributed to low intra-regional trade but rather encourage increased trading relations with powerful economic blocs and countries whose gross domestic products (GDP) dwarfs that of the entire Member States. Intra-regional trade also reflects the considerable economic heterogeneity of ECOWAS Member States, and the schisms between the majority of LDC's in the region and the stronger economies. Indeed, the strongest economies in the region, Nigeria (the economic hegemon in the region), Ghana, Cote D'Ivoire and Senegal, are important trade partners, despite "the well-known antagonisms between English-speaking and French-speaking West Africa" [13]. Further explanation for the low intra-ECOWAS trade and a more export-oriented trade policy should be looked from the perspectives of colonialism. Most of these countries were trapped in the primary production of products as a result of colonial policy of providing these products to feed European markets and later policies to establish import substitution industries in the early 1980's pushed these countries into huge debts. The colonial legacies and challenges of intra-trade among Member States raise serious questions applicability to the functionalism theory of integration in the sub-region. In a region and sub-region where the social sector was disorganized by colonialism and neo-colonialism, concentrating on the economic sector as the basis for regional integration is like building a castle without foundation. Yet, this is what the functionalist approach seems to logically dictate [7]. The economies of the countries in ECOWAS appear to have weak potential for significant trade growth based on the comparative advantage or on differentiated market characteristics. Beyond the apparent fundamental problems of trade generation within ECOWAS, the organization seems to be faced by additional disadvantages that can hinder trade [23]. Hanink and Owusu's assertion attests to the thesis that regional economic integration based on the new trade theory without a political agenda of the spillover effects of a moving towards some kind of federal system in the region may not escape the colonial trade pattern and the further exploitation of the differing resources of the various individual countries. The authors reiterate that political problems, both domestic and international, have hindered efforts at regional integration in SSA since the end of the colonial era. Critics of political integration (taking advantage of the spillover effect from integration as an end point and not a process) in the West African sub-region can point to a litany of reasons why the move from the sovereignty of states in integration to the creation of a political unity will not be possible. Critics of neo-functional theoretical framework for a political agenda towards a supranational organization based on political unity of government cites Nigeria's nationalistic tendencies and apathy towards political integration, the uneven size of member countries, unease over the incidence of costs and benefits of regional integration. Other challenges that will inhibit a political union includes common languages among some of the countries as a result of colonization, but none that is common, high transaction costs, interference by former colonial powers, ethnic diversity, institutional development, wars, and the "contagion effect: Nigeria's lethargy has adversely affected the rest of the region. ECOWAS countries with stronger economies also shape intra-regional trade flows in the region. In particular, given its economic dominance, Nigeria clearly acts as an economic driver in this and other goods trade, but also as political hegemon, blocking or pushing particular policy objectives or regional institutional reforms, 
underlining the need to understand its role in regional trade patterns and flows in key commodities being transported around the region [11]. Nigeria's recent announcement confirming that it is closing its borders to prevent movement of all goods has been met with harsh criticism from neighbors and regional integration advocates. The Buhari administration has justified the decision as a tactic to curb smuggling of goods which the country wants to internally increase production, such as rice [16]. The closure has also led to shortages of materials imported from Nigeria in neighboring countries and concerns about the consequences for the liberalization of trade. Experts say that the measures are in breach of the protocol on the free movement of goods, services and people established by the Economic Community of West African States (ECOWAS), to which Nigeria belongs and in which it wields significant political and economic clout [31]. Whatever the level of criticisms against any political agenda towards a political unity, there is no denying the fact that the legacies of colonialism, foreign interference and neo-colonialism are ingrained in the sub-region. Any collective attempt by the national political elites in the sub-region should first recognize the hands of foreign interference in any form. In order to halt foreign interference in the affairs of developing countries it is necessary to study, understand, expose and actively combat neo-colonialism in whatever guise it may appear. For the methods of neocolonialists are subtle and varied. They operate not only in the economic field, but also in the political, ideological and cultural practices [21]. The past decade has witnessed the ever-increasing influx of the non-traditional colonial trading partners in the economies of West African states, notably the Indians and the Chinese. Ostensibly, the direct and the large swaths of Chinese immigrants and businesses into the sub-region have raised questions about Chinese growing interests in the exploitation of the region's natural resources. The unprecedented level of involvement of Chinese interests in Africa and for that matter the West African sub-region has raised grave concerns among financial and trade experts both within and outside the continent. Nigerian Central Bank Governor Lamido Sanusi criticized China's engagement in Africa publicly in the Financial Times. His most quoted charge says "China takes from us primary goods and sells us manufactured ones. This was also the essence of colonialism. Sanusi's comment cast a negative shadow to Xi's first foreign visit and was met with ferocious rebuttals from an infuriated Beijing. China's Ministry of Commerce pointed to the western countries' "exploitation of African resources, trade of African people, occupation of African land and destruction of African culture" as the "essence of colonialism" and argued that it is China, not the West, that has provided support for Africa's economic and social development [28]. On the exploitation of the natural resources of the sub-region by foreign multinational corporations and governments and Immanuel Wallenstein's World System Theory [9] arguments on the "Core' relationship of less developed countries in the world economic systems, Kwame Nkrumah argues that neo-colonialism which is the last stage of imperialism has accorded American and European companies connected with the world's most powerful banking and financial institutions are, with the consent of African governments, entering upon major projects designed to exploit new sources of primary products. In West Africa, significant amounts of US private capital have been exported to Liberia, Nigeria, Gabon, Ghana and Guinea [27]. African countries are faced with the need to turn subsistence economies into organisms that will generate viable and improved conditions for their populations. However, many African governments, instead of getting together in united action which would stimulate maximum capital accumulation and the construction of a solid over all-African economy, are granting concessions for the working of mineral, agricultural and forestry resources whose purpose is the drawing off of output to sustain and enlarge and economies of imperialist countries. Not one of the investing syndicates has any intention of founding in any one of these countries an integrated industrial complex that would give impetus to genuine economic growth. Nor are the returns on the export of primary products from mining, agriculture and forestry likely to provide to any important extent and look-for capital for investing in industrial foundation [21]. Any meaningful effort to escape Nkrumah's neo-colonialism: powerful banking and financial institutions and extended tentacles of the Wall Street Octopus, the Invisible government, security agencies, religious organizations amongst other is the neo-functionalism spillover for the creation of a supranational organizations (political integration) above the nation states. The analogy of a supranational organization in West Africa above the individual nation state can be explicated through what Nkrumah iterated as the only effective way to challenge this economic empire and to recover possession of our heritage, is for us to act on a Pan African basis, through a Union Government. The neo-functionalism theoretical concept for the political agenda of creating a supranational organization with its spillover effects will help escape some of the destructive colonial legacies of ethnic conflicts, the problematic state, the Big Man rule and the external interference of controlling the regions natural resources and neo-colonialism. The kind of political integration at the regional level in the West African sub-region that will generate the much needed spillover effect for escaping neo-colonialism, economic growth and development and cooperation is the one which according Roger Kasperson and Julian Minghi [32], The Structure of Political Geography, is based on a structural framework of system of power and decision making, the sovereignty dependency status and governmental effectiveness. Sovereignty dependency status as the degree to which the political unit departs from the class status quo of sovereignty in which theoretically all members to a supreme political authority and political unity becomes completely independent from any outside control. Analyzing the structural framework of the political system, the authors argue that it provides a milieu within which the process operates, particularly with its aspects of territoriality and hierarchy [32]. A political system driving for integration maximizes its chances of achieving a high degree of integration and of remaining stable in spite of short run destabilizing effects if it is authoritarian, consensual, identificatory, and paternal [32]. Research into political integration over the past decades has been such as to render much in these early efforts in geography more of historical than contemporary interests. Three kinds/benefits of political 
integration: (a) effective control over violence, (b) a center of decision making that is able to effect significantly the allocation of resources and rewards through the community and (c) a dominant focus of political identification for the large majority of the political active citizens [32].

In conclusion, it is worth acknowledging the Euro-centric application of the theory of integration to ECOWAS, but to fully embrace the theory without examining the peculiarities and historicity of the states in the region amounts to what Frantz Fanon characterizes as Black Skin, White Mask. In this globalized world where there is a no-one size fit solution to all problems, the governments of the region should go back to the drawing board, examine the theory in its entirety by departing from its fundamental definition as a process with spillover effects to a political unity. In West Africa, where there are a cluster of challenges with spillover effects such as civil wars in one country impacting others, a political integration of all the states will have an effective control over violence.

\section{REFFERENCE}

1. Karl, D. (1957). Political Community and the North Atlantic Area.

2. Finn, L. (2007). Comparative Regional Integration: Theoretical Perspectives. Ashgate Publishing Limited. Burlington, VT.

3. Jones, E., \& Verdun, A. (2003). Political economy and European integration. Journal of european public policy, 10(1), 8183.

4. James Dougherty and Robert Pfaltzgraff. (1981). Contending Theories of International Relations: A Survey. Prentice Hall.

5. Adaawen, S. (2017). Challenges to Intra-Regional Migration and Economic Integration in West Africa: A Focus on Ghana and Nigeria

6. African Business Magazine, December 2, 2019. Nigeria Border Closure Causes Economic Shock.

7. Asobie, A. H. (2010). Conceptual and theoretical issues in regional integration in West Africa: The Nigerian perspective. Nation-states and the challenge of regional integration in West Africa, 21-40.

8. Aryeetey, E. (2001). "Regional Integration in West Africa. 2001. OECD Development Centre. Working Paper No. 170).

9. Bela, B. (1961). The Theory of Economic Integration. Richard D. Irwin, Inc. Homewood, Illinois.

10. Rosamond, B. (2005). The uniting of Europe and the foundation of EU studies: revisiting the neofunctionalism of Ernst B. Haas. Journal of European Public Policy, 12(2), 237-254.

11. Byiers, B., Vanheukelom, J. (2015). ATWA Phase 1 - Political Economy Considerations

12. Crawford, Y.(1994). The African Colonial State in Comparative Politics Yale University Press.

13. Engel, J., \& Jouanjean, M. A. (2015). Political and economic constraints to the ECOWAS regional economic integration process and opportunities for donor engagement. EPA PEAKS-Economic and Private Sector, Professional and Applied Knowledge Services.

14. Ernst Haas and Philippe Schmitter. (1964). Mexico and Latin America Economic Integration.

15. EU-West Africa Economic Partnership Agreement. (2017).

16. Golub, S. S., Mbaye, A. A., \& Golubski, C. (2019). The Effects Of Nigeria's Closed Borders On Informal Trade With Benin. Brookings Institution: Africa In Focus.

17. Hyden, G. (2012). African politics in comparative perspective. Cambridge University Press.

18. Lelieveldt, H., \& Princen, S. (2015). The politics of the European Union. Cambridge University Press.

19. Iyoha, M. A. (1984). Economic development and trade theories: Relevance and implications for ECOWAS. Trade and Development in Economic Community of West African States, p31.(Stosius Inc/Advent Books Division, 1984).

20. Michelle Cini. (2007). European Union Politics. Oxford University Press. Great Claredon St., Oxford.

21. Nkrumah, K. (1967). Neo-colonialism: The last stage of imperialism.

22. Osabuohien, E. S., Odebiyi, J. T., Efobi, U. R., \& Fayomi, O. O. (2017). Financial development, trade costs and bilateral trade flows: connecting the nexus in ECOWAS. In Investment and Competitiveness in Africa (pp. 153-175). Springer, Cham.

23. Hanink, D. M., \& Owusu, J. H. (1998). Has ECOWAS promoted trade among its members?. Journal of African Economies, 7(3), 363-383.

24. Ogunkola, E. O. (1994). An Empirical Evaluation of Trade Potential in ECOWAS. Final Report, The African Economic Research Consortium (AERC), Nairobi.

25. Ravenhill, J. (Ed.). (2017). Global political economy. Oxford University Press.

26. Rosamond, B. (2000). Theories of European integration.

27. Smith, S.(1974). US Neocolonialism in Africa. 1974. International Publishers, New York.

28. Sun, Y.(2013). China's Increasing Interest in Africa: Benign but Hardly Altruistic. Brookings Education.

29. United Nations Conference on Trade and Development (2018). Regional Integration and Non- Tariff Measures in Economic Community of West African States.

30. Hyden, G. (2012). African politics in comparative perspective. Cambridge University Press.

31. Magazine, A. B. (2019). August-September 2019-African Business Magazine.[Online] Available at https://africanbusinessmagazine. com/magazine/august-september-2019.

32. Kasperson, R. E., \& Minghi, J. V. (Eds.). (2011). The structure of political geography. Transaction Publishers. 